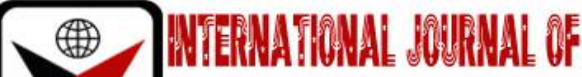

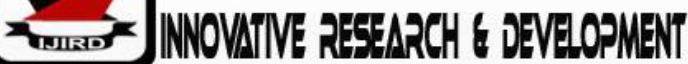

ISSN 2278-0211 (Online)

\section{Assessment of Heavy Metals Concentrations in Selected Crustaceans and Their Potential Health Risk at Qua Iboe Estuary, Ibeno}

\begin{tabular}{|c|}
\hline Essien, Ekemini S. \\
Research fellow, Environmental Management \\
Federal University of Technology, Owerri, Nigeria \\
Okeke, Peter N. \\
Lecturer, Environmental Management \\
Federal University of Technology, Owerri, Nigeria \\
Bassey, Uwakmfon L \\
Research Fellow, Environmental Management \\
Federal University of Technology, Owerri, Nigeria
\end{tabular}

\begin{abstract}
:
This study was conducted to assess the accumulation of some metals ( $\mathrm{Pb}, \mathrm{Cu}, \mathrm{Zn}$, Cd, and $\mathrm{Mn}$ ) in the tissues of Procambarus clarkii and Callinectes amnicola, in Qua Iboe Estuary, Ibeno. Four locations were selected, three within Qua Iboe Estuary- Mkpenak, Ukpenekang, and Iwo-Okpom, while the fourth, Ifiayong, served as control.Water and Sediment samples were also collected from the same locations. Standard procedures were employed insample preparation and elemental analysis was carried outusing Atomic Absorption Spectrophotometer (AAS).The results obtained showed that the various concentrations of the metals in water was in the order Mn>Cu>Zn>Cd>Pb at all study locations, and that concentrations of Cd $(0.058 \pm 0.01 \mathrm{mg} / \mathrm{l})$ and $\mathrm{Mn}(1.086 \pm 0.81 \mathrm{mg} / \mathrm{l})$ were found to be higher than WHO permissible range, while others $(\mathrm{Pb}, \mathrm{Cu}$, and $\mathrm{Zn})$ were withinthe range.In sediments, all concentrations of metals were higher than their values in the overlaying waterand were within the allowable range except for Mn (80.805 \pm $6.80 \mathrm{mg} / \mathrm{kg}$ ).Also, concentrations of $\mathrm{Cu}$ and $\mathrm{Zn}$ in crustacean tissues were lower than the international permissible levels. However, $\mathrm{Pb}, \mathrm{Cd}$ and $\mathrm{Mn}$ exceeded the allowable limits given by FAO/WHO. From calculations, the estimated weekly intake (EWI) for all metals were considerably below the provisional tolerable weekly intake based on the FAO/WHO standards.The Hazard index (HI) for the studied metals in P. clarkii and C. amnicolawere0.474 and 0.370 respectively, showing the absence of potential significant health risk through the ingestion of the crustaceans.The cancer risk factors for $\mathrm{Pb}\left(3.2 \times 10^{-7}\right.$ and $2.7 \times 10^{-7}$ in crabs and crayfish respectively) were below the acceptable lifetime carcinogenic risk $\left(10^{-5}\right)$. Relative to the permissible limits for metals in seafood, there was an absence of sufficient accumulation of any of the investigated metals in the crustacean samples to indicate a potential significant health hazard from their consumption. The results of this study revealed a safe level of $\mathrm{Pb}, \mathrm{Cu}, \mathrm{Cd}, \mathrm{Zn}$, and $\mathrm{Mn}$ contents in the crustaceans consumed by the population.
\end{abstract}

Keywords: Heavy metals, Bioaccumulation, Qua Iboe Estuary, Procambarus clarkii, Callinectes amnicola

\section{Introduction}

Coastal environments are usually densely populated and urbanized with various industries operating within its proximity. These industries produce various waste streams with diversified obnoxious constituents, which are usually not managed or treated to recommended limits before disposal. Amongst these components, heavy metals, which are natural constituents of the environment, and generally occur in low concentrations, have attracted global concerns because anthropogenic activities have inadvertently raised the levels of metals in many of the natural water systems, leaving them in polluted conditions.

Mine drainage, offshore oil and gas exploration, industrial effluents (pesticides, paints, leather, textile, fertilizers and pharmaceuticals), agricultural runoff, and acid rain have all contributed to the increased metal burden in these waters being ultimately incorporated into aquatic sediments (Güner, 2010). The uncontrolled discharge of these pollutants into the freshwaters cause many dramatic problems to most of the aquatic fauna. Heavy metals constitute a major problem because they are toxic and tend to accumulate in the body organs (Vilizzi and Takan, 2016). These metals are neither degraded nor metabolised, which leads to their ultimate persistence in the environment.

The ability of heavy metals to accumulate in marine animals is of great scientific interest as far as the knowledge of heavy metal is concerned (Kumar and Hema, 2007). Aquatic animals may absorb dissolved metals from surrounding 
waters and sediments which may accumulate in various tissues in significant amounts and elicit toxicological effects at critical targets. Macro invertebrates are frequently suggested as bioindicators for monitoring changing water conditions in areas of potential contamination (Morse, Bae, and Munkhjargaletal, 2007). Therefore, the determination of harmful and toxic substances in water, sediments and biota gives direct information on the significance of pollution in the aquatic environment.

Qua Iboe Estuary is an outlet of the parent river, Qua Iboe River, which traverses through the rain forests in Abia and Akwa Ibom states. Therefore, pollution by heavy metals is an indicator to the environmental pollution by numerous local economic activities in this terrain. This study aims to determine the bioaccumulation of heavy metals in crabs and crayfish from the Estuary. The human health risk assessment of the heavy metals by dietary intake through crabs and crayfish is also investigated.

\section{Materials and Methods}

\subsection{The Study Area}

The Qua Iboe Estuary is a major and commercially important hydrographic feature in the Niger Delta (Benson and Essien, 2009). The estuary lies within latitude $4^{\circ} 30^{\prime}-4^{\circ} 45^{\prime} \mathrm{N}$ and longitude $7^{\circ} 30^{\prime}-8^{\circ} 45^{\prime} \mathrm{E}$ on the southeastern coastline of Nigeria and it is in close proximity to the Exxon-Mobil oil terminal and effluent treatment/discharge site. Socio-economic activities thrive along the bank of the estuary, and the population depend mainly on the estuary for most of their domestic, economic and recreational activities. There is a constant exchange of organic and inorganic substances between the estuary and the ocean through backwash infiltration.

In this study, four locations were selected, three within the Estuary- Mkpanak, Ukpenekang, and Iwo-Okpom, while the fourth location, Ifiayong, served as control.

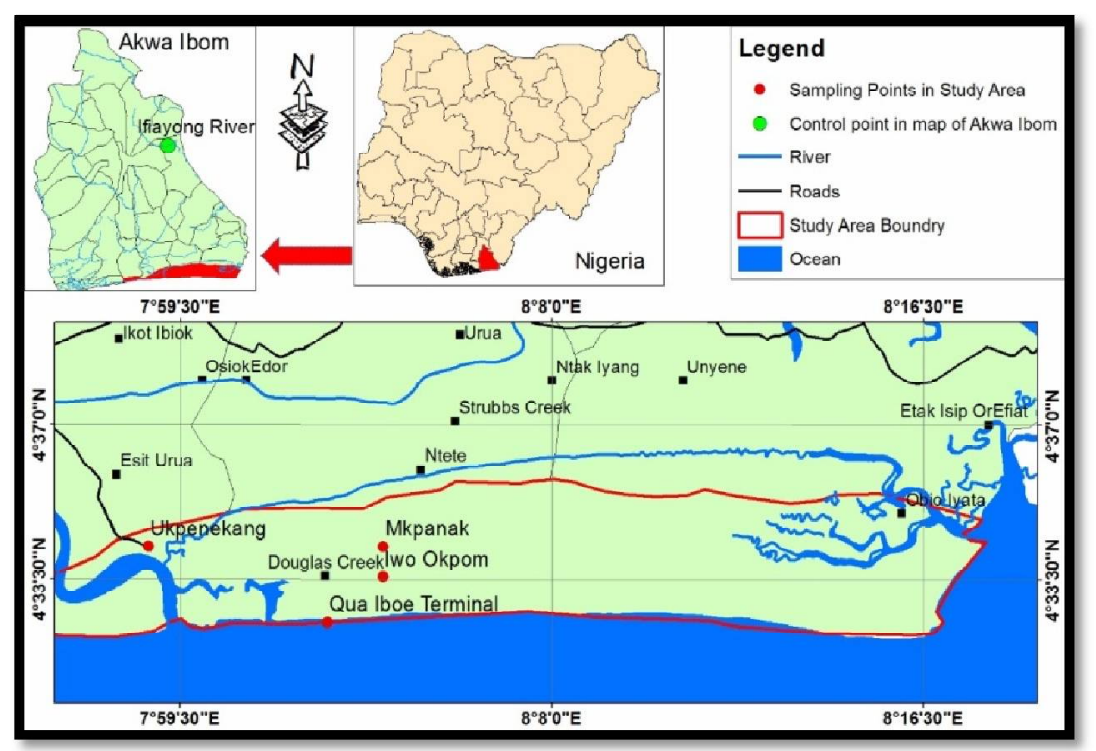

Figure 1: Map of Study Area Showing Sampling Locations

\subsection{Sample Collection and Preparation}

Water samples from the four study locations were collected in triplicate form into pre-cleaned plastic bottles, and treated with $2 \mathrm{ml} \mathrm{NHO}_{3}$. Before sampling, the bottles were rinsed with water from sampling location, and immersed to about $30-50 \mathrm{~cm}$ below the water surface to prevent contamination of heavy metals from air. They were stored in aniced box and transported to the laboratory. In the laboratory, triplicate water samples were thoroughly mixed and aliquots of $50 \mathrm{ml}$ digested with a mixture of nitric and perchloric acid in a ratio of $4: 1$. Samples were heated on a hot plate in a fume cupboard at $120-150^{\circ} \mathrm{C}$ for 40 minutes until clear solutions were obtained. Digests were filtered, diluted to $50 \mathrm{ml}$ with distilled water and stored in labelled plastic bottles for analysis.

Sediment samples were collected from the same locationsas water. At each point, three sediment samples were taken using Eckman bottom sampler, and stored in pre-cleaned plastic containers and packed separately in polyethylene bags. These samples were air-dried in the laboratory for 72 hours, disaggregated and sieved through a $2 \mathrm{~mm}$ mesh to remove large debris, gravels and other unwanted materials. Samples were digested with $10 \mathrm{ml}$ of concentrated $\mathrm{HNO}_{3}$ and $\mathrm{HClO}_{4}$ in the ratio of 4:1 as described by Vowotor et al. (2014).

Samples of $P$. clarkii and $C$. amnicola were collected from the study locations using containers and diagonal nets. The collected crustaceans were stored in ice and later transported alive to the laboratory. In the laboratory, the crustaceans were washed with distilled water, oven-dried at $105^{\circ} \mathrm{C}$ for 24 hours and then transferred to a desiccators until it reached a constant weight.The dried samples were ground to fine particles using a clean mortar and pestle. The mortar and pestle were properly cleaned after grounding each specimen to avoid contamination (Prendez and Carrasco, 2003).0.5g each of powdered samples was weighed into a clean dried beaker and digested with $5 \mathrm{ml}$ of a mixture of $\mathrm{HNO}_{3}$ and $\mathrm{HClO}_{4}$ in the ratio of $4: 1$. The mixture was heated up to $140{ }^{\circ} \mathrm{C}$ on a hot plate in a fume cupboard to obtain a clear solution. The solution was filtered, diluted to $50 \mathrm{ml}$ and stored in bottles for analysis. Metals concentrations were 
measured using Atomic Absorption Spectrophotometer (Model A-Varian Spectra 100, Australia), according to IAEA, (1980).The accuracy and precision of the analytical procedure were determined. Metals measured in water, sediment and crayfish tissues were Lead (Pb), Copper (Cu), Manganese (Mn), Zinc ( $\mathrm{Zn})$, and Cadmium (Cd).

\subsection{Estimated Daily Intake}

The Estimated Daily Intake (EDI) was calculated by the following equation:

$$
E D I=\underline{E}_{E} \times E_{\underline{D}} \times F_{I \underline{R}} \times \frac{C_{F}}{W_{A B} \times C_{\underline{M}}} \times 10^{-3}
$$

Where $E_{F}$ and $E_{D}$ are the exposure frequency (365 days/year) and the exposure duration (60 years) (Saha et al., 2016), respectively; $F_{I R}$ is the ingestion rate of seafood ( $25 \mathrm{~g} /$ day); $\mathrm{C}_{\mathrm{F}}$ is the conversion factor. A $\mathrm{C}_{\mathrm{F}}$ of 0.208 is to convert fresh weight crustaceans to dry weight (Saha et al., 2016); $\mathrm{C}_{\mathrm{m}}$ is the metal concentration in the crustaceans tissues (mg/kg); $\mathrm{W}_{\mathrm{AB}}$ is the average body weight for adults ( $65 \mathrm{~kg}$ ); and $\mathrm{T}_{\mathrm{A}}$ is the average exposure time for non-carcinogens (equal to $\mathrm{E}_{\mathrm{F}} \times \mathrm{E}_{\mathrm{D}}$ ) (Saha et al., 2016).

\subsection{Daily Consumption Limit}

The daily consumption rate limit $\left(\mathrm{CR}_{\mathrm{lim}}\right)$ of crab and crayfish, based on the carcinogenic effect of the contaminants, was calculated by the following equation:

$$
C R_{\text {lim }}=\frac{\left(A R L \times W_{A B}\right)}{C S F \times \frac{C_{m}}{C}}
$$

Based on the non-carcinogenic effects of the contaminants, the maximum allowable daily consumption of crab and crayfish was determined using the following equation:

$C R_{\text {lim }}=\frac{\left(R f D \times W_{A B}\right)}{C_{m}}$

Where $\mathrm{CR}_{\lim }$ is the maximum allowable daily consumption of contaminated crustaceans (kg/day), ARL indicates the maximum acceptable individual lifetime risk level (in the present study, $10^{-5}$ was used as set by USEPA (Yu et al., 2014)), $\mathrm{W}_{\mathrm{AB}}$ is the mean body weight of consumer population (kg), CSF is the cancer slope factor; RfD refers to the oral reference dose (mg/kg-day), and $\mathrm{C}_{\mathrm{m}}$ is the metal concentration in the edible part of the crustaceans $(\mathrm{mg} / \mathrm{kg}$ ) (Alipour et al., 2015).

\subsection{Target Hazard Quotient}

Non-carcinogenic risk was investigated using the target hazard quotient (THQ), which is the ratio between the estimated exposure (estimated daily intake (EDI)) and the oral reference dose (RfD). RfD (mg/kg bw/day) represents an estimate of the daily oral exposure of the human population that is likely to be without an appreciable risk of deleterious effects.

The following equation was used to calculate the THQ (Saha et al., 2016):

$$
\begin{gathered}
T H Q=E D I \\
R f D
\end{gathered}
$$

A THQ less than 1 reveals that there is no adverse hazard of the exposed population. A THQ equal to 1 indicates that the concerned receptors may experience non-carcinogenic health risk, while the probability should increase as the THQ value increases. In calculating the THQ the effect of cooking on the concentration of contaminants was not considered and the ingestion dose was assumed to be equal to the absorbed dose of the contaminant (Saha et al., 2016).Based on literature, exposure to two or more pollutants may cause synergistic effects, and hence, the combined target hazard quotient (CTHQ) may be calculated. The CTHQ gives an overview of health risks of the five studied metals $(\mathrm{Pb}, \mathrm{Cd}, \mathrm{Zn}, \mathrm{Cu}$, and $\mathrm{Mn}$ ) together through crayfish consumption.

The CTHQ was calculated according to the following equation:

$\mathrm{CTHQ}=\Sigma T H Q$

\subsection{Cancer Risk}

The cancer risk (CR) over a lifetime of exposure to $\mathrm{Pb}$ was estimated using the cancer slope factor according to Equation 6 (Peng et al. 2016; Shaheen et al. 2016):

$$
\mathrm{CR}=\underline{E}_{F} \times E_{\underline{D}} \times F_{I R} \times \frac{C_{F} \times C_{M}}{W_{A B} \times C S F} \times 10^{-3}
$$

Where CSF is the cancer slope factor $(\mathrm{mg} / \mathrm{kg} /$ day), while the other parameters have been defined previously. The US Environmental Protection Agency set an acceptable lifetime carcinogenic risk of $10^{-5}$ (Saha et al., 2016).

\section{Results and Discussion}




\subsection{Heavy Metal Contents in Water, Sediment, Crayfish and Crab}

Heavy metal concentrations in sample matrices in Qua Iboe Estuary and Ifiayong are presented in Tables $1 \& 2$. Results revealed that average concentrations of heavy metals in all the study samples was in the order $\mathrm{Mn}>\mathrm{Cu}>\mathrm{Zn}>\mathrm{Cd}>$ $\mathrm{Pb}$. Generally, metals were lower in water column than in the other samples. These low concentrations of metals in water corroborate studies done by several authors whose findings indicated that metal concentration is usually lower in water, but will show a dramatic increase in the sediment and the biota of the specific aquatic system (Varol and Şen, 2012; Vicente-Martorell et al. 2009)

\begin{tabular}{|c|c|c|c|c|c|}
\hline Sample & Pb & Cu & Zn & Cd & Mn \\
\hline Water & $0.008 \pm 0.00$ & $0.694 \pm 0.12$ & $0.228 \pm 0.06$ & $0.064 \pm 0.01$ & $1.427 \pm 1.24$ \\
\hline Sediment & $0.453 \pm 0.21$ & $19.636 \pm 5.78$ & $4.774 \pm 0.74$ & $0.965 \pm 0.03$ & $80.805 \pm 6.80$ \\
\hline Crayfish & $0.472 \pm 0.13$ & $38.019 \pm 1.96$ & $5.706 \pm 0.47$ & $1.186 \pm 0.06$ & $32.264 \pm 4.85$ \\
\hline Crab & $0.324 \pm 0.05$ & $42.569 \pm 1.67$ & $8.458 \pm 0.67$ & $1.078 \pm 0.01$ & $54.268 \pm 10.40$ \\
\hline
\end{tabular}

Table 1: Concentration of Heavy Metals Expressed as $\mathrm{Mg} / \mathrm{L}$ in Water and $\mathrm{Mg} / \mathrm{Kg}$ in Sediment and Crustaceans in Qua Iboe Estuary

\begin{tabular}{|c|c|c|c|c|c|}
\hline Sample & Pb & Cu & Zn & Cd & Mn \\
\hline Water & $0.001 \pm 0.00$ & $0.099 \pm 0.01$ & $0.182 \pm 0.17$ & $0.037 \pm 0.03$ & $0.063 \pm 0.04$ \\
\hline Sediment & $0.020 \pm 0.01$ & $14.380 \pm 0.02$ & $3.626 \pm 0.30$ & $0.410 \pm 0.20$ & $10.944 \pm 0.03$ \\
\hline Crayfish & $0.068 \pm 0.04$ & $17.610 \pm 3.51$ & $4.697 \pm 1.24$ & $1.350 \pm 0.07$ & $10.868 \pm 4.94$ \\
\hline Crabs & $0.025 \pm 0.01$ & $12.800 \pm 1.27$ & $3.953 \pm 0.50$ & $0.000 \pm 0.00$ & $14.558 \pm 2.50$ \\
\hline
\end{tabular}

Table 2: Concentration of Heavy Metals Expressed $\mathrm{As} \mathrm{Mg} / \mathrm{L}$ in Water and $\mathrm{Mg} / \mathrm{Kg}$ in Sediment and Crustaceans Ifiayong

The concentrations of $\mathrm{Pb}$ in all study samples remained considerably low. $\mathrm{Pb}$ levels in crabs, crayfish and sediment were relatively higher than the level obtained in water. Also, at the control location, all samples showed lower values of $\mathrm{Pb}$ comparative to the estuarine samples.

From Table 1, the mean concentration of $\mathrm{Pb}$ in water was lower than $0.01 \mathrm{mg} / \mathrm{l}$, the recommended concentration of $\mathrm{Pb}$ for drinking water as prescribed by the World Health Organization (WHO, 2004).Pb However, in crayfish and crabs, concentrations were above the WHO recommended level of $0.002 \mathrm{mg} / \mathrm{kg}$ in seafood, which suggested that the investigated crustaceans had accumulated the metal in considerable amounts.

According to Kouba et al. (2010), Pb is neither essential nor relevant to living organisms and has been known for centuries to be a cumulative metabolic poison. Also, $\mathrm{Pb}$ is a mutagen and teratogen, and therefore has carcinogenic properties which could impair reproduction, impede liver and thyroid functions, and interferes with resistance to infectious diseases(Güner, 2010).

The mean concentration of $\mathrm{Cu}$ in both the estuarine and control water samples were below the WHO recommended $2 \mathrm{mg} / \mathrm{l}$, though they maintained a considerable variation between the two locations (Tables 1 and 2 ). Copper is moderately soluble in water and binds easily to sediments and organic matter, indicating that there is usually a huge amount of the metal in sediments and benthic organisms than in the overlying water column. The levels of $\mathrm{Cu}$ in sediments were markedly elevated relative to those obtained in the water (Table 1), which corroborates the assertion that sediments remain a potential repository for every pollutant that gains entry into the aquatic space. From results, average $\mathrm{Cu}$ concentrations were higher in crabs than in crayfish and this could be due to the differences in size, assimilation efficiency or excretive capacity.

As observed in this study, concentrations of $\mathrm{Cu}$ in P. clarkii and C. amnicola were above the $3 \mathrm{mg} / \mathrm{kg}$ recommended by the WHO for seafood. This is an indication that accumulation of $\mathrm{Cu}$ may have occurred, as there seemed to be higher levels of the metal in the organism than in the water and sediment samples.

Copper is an essential trace nutrient that is required in trace amounts (5-20 $\mathrm{g} / \mathrm{g}$ ) by humans, other mammals, fish and shellfish for carbohydrate metabolism and the functioning of enzymes. However, copper toxicity may result in gastrointestinal defects, hepatic necrosis, damaged cornea, kidney failure and even death (Ferenci et al., 2015).

The concentrations of $\mathrm{Zn}$ in all sample matrixes were considerably lower than international permissible limits. From Table $1, \mathrm{Zn}$ in water had a mean value of $0.228 \pm 0.06 \mathrm{mg} / \mathrm{l}$, which is below the recommended $3 \mathrm{mg} / \mathrm{l}$ for drinking water $(\mathrm{WHO}$, 2004). Sediment, which generally accumulates higher proportion of metals relative to water, had a mean of $4.774 \pm 0.74 \mathrm{mg} / \mathrm{kg}$ which was below the limit of $123 \mathrm{mg} / \mathrm{kgestablished} \mathrm{by} \mathrm{the} \mathrm{WHO.} \mathrm{Concentrations} \mathrm{of} \mathrm{Zn} \mathrm{in} \mathrm{tissues} \mathrm{of}$ crustaceans were also below the $30 \mathrm{mg} / \mathrm{kg}$ respectively, indicating that $\mathrm{Zn}$ had low concentrations in the studied environment. Zinc is required for normal physiological function in the human body. Genetic expression, cell division, protein synthesis, immune functions, wound healing, and normal growth are some of the basic functions zinc. Nevertheless, signs of zinc toxicity include vomiting, diarrhea, lack of appetite, abdominal pain, headaches, and lethargy.Other adverse effects include kidney failure, prostatitis, pale gums, menstrual problems, ovarian cysts and muscle spasms (Nriagu, 2007).

Cadmium (Cd) is classified as an environmental pollutant with severe toxicity to humans and animals, and is also recognized globally as an occupational hazard. Industrial applications have caused great abundance of the element in the environment with various routes of exposure. The mean concentration of Cd in water was $0.064 \pm 0.01 \mathrm{mg} / \mathrm{l}$ and was higher than the value obtained at the control location (Table 2). The mean value of $\mathrm{Cd}$ in this study exceeded the benchmark of 
0.003mg/l recommended for Cd in drinking water by the WHO. According to Güner (2010), cadmium contamination in drinking water sources may originate from untreated industrial sewage, impurities in galvanized zinc pipes and agricultural runoff. The mean concentration of $\mathrm{Cd}$ in sediment was $0.96 \pm 0.03 \mathrm{mg} / \mathrm{kg}$, and was lower than $6 \mathrm{mg} / \mathrm{kg}$ recommended for unpolluted sediment by the WHO. Hence, concentrations of $\mathrm{Cd}$ in sediments might not have reached the nuisance level as a consequence of several economic activities around this ecosystem. Crustaceans in Qua Iboe Estuary accumulated $\mathrm{Cd}$ in higher proportions than in water and sediment. Mean concentrations of Cd in crabs and crayfish were slightly above unity and had exceeded the $0.05 \mathrm{mg} / \mathrm{kg}$ recommended limit (WHO, 2004). Cd is a non-essential metal and has the potential to cause nephro-toxicity, immuno-toxicity, osteo-toxicity, teratogenicity, carcinogenicity, and reproductive toxicity (Samuel et al., 2012).

The mean concentration of $\mathrm{Mn}$ in water was $1.427 \pm 1.24 \mathrm{mg} / \mathrm{l}$ and far exceeded the recommended $0.4 \mathrm{mg} / \mathrm{lthres}$ hold prescribed by WHO. However, concentration of Mn at the control location $(0.063 \pm 0.04)$ was below the permissible threshold. Manganese is one of the most abundant metals in the Earth's crust, usually occurring with iron. It is used principally in the manufacture of iron and steel alloys, as an oxidant for cleaning, bleaching and disinfection as potassium permanganate and as an ingredient in various products (WHO, 2004).

Manganese revealed very high concentrations in sediments with a mean of $80.805 \pm 6.80 \mathrm{mg} / \mathrm{kg}$ and was the only metal with such elevated level in sediment samples. This mean was higher than $30 \mathrm{mg} / \mathrm{kg}$ stipulated limit for Mn in unpolluted sediment (WHO, 2004). Mean concentrations in crustaceans were $32.264 \pm 4.85 \mathrm{mg} / \mathrm{kg}$ and $54.268 \pm 10.40 \mathrm{mg} / \mathrm{kg}$ for crayfish and crabs respectively. Results revealed that crabs accumulated more Mn than crayfish in its tissues and this may have been due to differences in size or filtration efficiency.Mn accumulation in high concentrations may have a toxic effect and pose some negative environmental and health problems to the aquatic organisms and humans (Tunca et al., 2013).

\subsection{Consumption Rate Limits}

The Estimated Daily Intake (EDI) of the five heavy metals for both crayfish and crabs is presented in tables 3 and 5. The Estimated Weekly Intake (EWI) were calculated and compared with the Provisional Tolerable Weekly Intake (PTWI) established by FAO/WHO. The EDI of the five heavy metals studied was determined based on the assumption of $65 \mathrm{~kg}$ body weight per person and exposure duration of 60 years. As presented in tables 3 and 5, the maximum daily intake for both crayfish and crabs was in the order $\mathrm{Cu}>\mathrm{Mn}>\mathrm{Zn}>\mathrm{Cd}>\mathrm{Pb}$.

In this study, the average EWI values were significantly below the PTWI values for all the studied metals, indicating that the values are within safe range.

The PTWI is a reference dose set by the WHO/FAO Joint Expert Committee on Food Additive (JECFA). It represents a safe weekly intake of pollutants (Ostos et al., 2015).

\begin{tabular}{|c|c|c|c|}
\hline Metal & PTWI (mg/kg bw/week) & EDI (mg/kg bw/day) & EWI (mg/kg bw/week) \\
\hline $\mathrm{Pb}$ & 0.025 & $3.81 \times 10^{-5}$ & $2.67 \times 10^{-4}$ \\
\hline $\mathrm{Cu}$ & 3.500 & $3.07 \times 10^{-3}$ & $2.15 \times 10^{-2}$ \\
\hline $\mathrm{Zn}$ & 7.000 & $4.60 \times 10^{-4}$ & $3.22 \times 10^{-3}$ \\
\hline $\mathrm{Cd}$ & 0.007 & $9.56 \times 10^{-5}$ & $6.69 \times 10^{-4}$ \\
\hline $\mathrm{Mn}$ & 0.980 & $2.60 \times 10^{-3}$ & $1.82 \times 10^{-2}$ \\
\hline
\end{tabular}

Table 3: Estimated EDI and EWI through Consumption of P. Clarkii

${ }^{A}$ source: Iwegbue (2015)

\begin{tabular}{|c|c|c|c|c|c|c|}
\hline Metal & $\begin{array}{c}\text { RfD } \\
\text { (mg/kg } \\
\text { bw/day) }\end{array}$ & $\begin{array}{c}\text { Non-carcinogenic } \\
\text { CRI }_{\text {im }} \text { (kg/day) }\end{array}$ & $\begin{array}{c}\text { Carcinogenic } \\
\text { CR }_{\text {lim }} \text { (kg/day) }\end{array}$ & THQ & CSF & CR \\
\hline $\mathrm{Pb}$ & $\mathbf{0 . 0 0 4}$ & $\mathbf{0 . 5 5 1}$ & $\mathbf{0 . 2 0 6}$ & $\mathbf{0 . 0 1 0}$ & $\mathbf{8 . 5 \times 1 0 ^ { - 3 }}$ & $\mathbf{3 . 2 \times 1 0 ^ { - 7 }}$ \\
\hline $\mathrm{Cu}$ & $\mathbf{0 . 0 4 0}$ & $\mathbf{0 . 0 6 8}$ & - & $\mathbf{0 . 0 7 6}$ & - & - \\
\hline $\mathrm{Zn}$ & $\mathbf{0 . 3 0 0}$ & $\mathbf{3 . 4 1 8}$ & - & $\mathbf{0 . 0 0 2}$ & - & - \\
\hline $\mathrm{Cd}$ & $\mathbf{0 . 0 0 1}$ & $\mathbf{0 . 0 5 5}$ & - & $\mathbf{0 . 0 9 6}$ & - & - \\
\hline $\mathrm{Mn}$ & $\mathbf{0 . 0 1 4}$ & $\mathbf{0 . 0 2 8}$ & - & $\mathbf{0 . 1 8 6}$ & - & - \\
\hline
\end{tabular}

Table 4: Estimated CR $R_{\text {lim }}$ THQ, CSF and CR of P. clarkii

aSource: Alipour et al. (2015) 


\begin{tabular}{|c|c|c|c|}
\hline $\mathrm{Pb}$ & $\mathbf{0 . 0 2 5}$ & $2.61 \times 10^{-5}$ & $1.63 \times 10^{-4}$ \\
\hline $\mathrm{Cu}$ & 3.500 & $3.43 \times 10^{-3}$ & $2.40 \times 10^{-2}$ \\
\hline $\mathrm{Zn}$ & 7.000 & $6.62 \times 10^{-4}$ & $4.77 \times 10^{-3}$ \\
\hline $\mathrm{Cd}$ & 0.007 & $8.69 \times 10^{-5}$ & $6.08 \times 10^{-4}$ \\
\hline $\mathrm{Mn}$ & 0.980 & $4.38 \times 10^{-3}$ & $3.06 \times 10^{-2}$ \\
\hline
\end{tabular}

Table 5: Estimated EDI and EWI through consumption ofC. amnicola

\begin{tabular}{|c|c|c|c|c|c|c|}
\hline Metal & $\begin{array}{c}\text { RfD } \\
\text { (mg/kg } \\
\text { bw/day) }\end{array}$ & $\begin{array}{c}\text { Non-carcinogenic } \\
\text { CR }_{\text {lim }} \text { (kg/day) }\end{array}$ & $\begin{array}{c}\text { Carcinogenic } \\
\text { CR }_{\text {lim }} \text { (kg/day) }\end{array}$ & THQ & CSF & CR \\
\hline $\mathrm{Pb}$ & $\mathbf{0 . 0 0 4}$ & $\mathbf{0 . 3 2 4}$ & $\mathbf{0 . 2 3 2}$ & $\mathbf{0 . 0 0 6}$ & $\mathbf{8 . 5 \times 1 0 ^ { - 3 }}$ & $\mathbf{2 . 7 \times 1 0 ^ { - 7 }}$ \\
\hline $\mathrm{Cu}$ & $\mathbf{0 . 0 4 0}$ & $\mathbf{0 . 0 6 1}$ & - & $\mathbf{0 . 0 6 6}$ & - & - \\
\hline $\mathrm{Zn}$ & $\mathbf{0 . 3 0 0}$ & $\mathbf{2 . 3 0 6}$ & - & $\mathbf{0 . 0 0 2}$ & - & - \\
\hline $\mathrm{Cd}$ & $\mathbf{0 . 0 0 1}$ & $\mathbf{0 . 0 6 0}$ & - & $\mathbf{0 . 0 8 7}$ & - & - \\
\hline $\mathrm{Mn}$ & $\mathbf{0 . 0 1 4}$ & $\mathbf{0 . 0 1 7}$ & - & $\mathbf{0 . 3 1 3}$ & - & - \\
\hline
\end{tabular}

Table 6: Estimated CR $R_{\text {lim }}, T H Q, C S F$ and CR of C. amnicola

In order to characterize the risk of crustacean consumption by the estuarine population, some health risk parameters were investigated and the results are presented inTables 4 and 6. From calculations, the combined target hazard quotient for the five studied metals in Crabs and Crayfish were 0.474 and 0.370 respectively, i.e., below 1 , showing the absence of potential significant health risk through the ingestion of the crustaceans. The CR factor for $\mathrm{Pb}$ over a lifetime of exposure through contaminated crabs and crayfish consumption were $1.7 \times 10^{-7}$ and $2.6 \times 10^{-7}$ respectively. The USEPA set a value of $10^{-5}$ (1 for 100,000) as an acceptable lifetime carcinogenic risk (Saha et al., 2016). In comparison with is value, this implies that the $\mathrm{CR}$ of $\mathrm{Pb}$ appears to be negligible. The results of this study revealed safe levels of $\mathrm{Pb}, \mathrm{Cu}, \mathrm{Zn}, \mathrm{Cd}$, and Mn contents in investigated crustaceans consumed by this population.

\subsection{Conclusion}

This study was designed to assess the concentrations of heavy metals in samples of selected crustaceans in Qua Iboe Estuary, Ibeno. The associated health risk assessment of these heavy metals was also investigated to ascertain the degree of safety for consumption. P. clarkii and C. amnicola harvested from this study location are safe for consumption as there was no sufficient accumulation of any of the investigated metals in crabs and crayfish to indicate a potential significant health hazard from their consumption. However, there is need to conduct continuous monitoring for commercial fish markets to ensure that the concentrations of metals remain within the prescribed safe threshold.

\section{References}

i. Alipour, H., Pourkhabbaz., A., and Hassanpour, M. (2015). Estimation of potential health risks for some metallic elements by consumption of fish. Water Quality, Exposure and Health, 7(2): 179-185.

ii. Benson, N. and Essien, J. (2009). Petroleum hydrocarbons contamination of sediments and accumulation in Tympanotonus fuscatus var. radula from the Qua Iboe Mangrove Ecosystem, Nigeria. Current Science, 92(2): 238244.

iii. Güner, U. (2010) Bioaccumulation of Some Heavy Metals on Freshwater Crayfish. Pollution Science, Technology and Abatement, Impact, Monitoring and Management of Environmental Pollution. ISBN: 978-1-60876-4877.

iv. Ferenci, P., Litwin, T., Seniow, J., and Czlonkowska, A. (2015). Encephalopathy in Wilson's disease: copper toxicity or liver failure? Journal of Clinical and Experimental Hepatology, 5(1): 88-95. doi:http://dx.doi.org/10.1016/j.jceh.2014.09.002.

v. International Atomic Energy Agency (1980). Elemental analysis of biological materials. Current problems and techniques with special references to trace elements. International Atomic Energy Agency (IAEA), Vienna. Technical Reports.

vi. Iwegbue, C.M. (2015). Metal concentrations in selected brands of canned fish in Nigeria: estimation of dietary intakes and target hazard quotients. Environmental Monitoring and Assessment, 187(3),85. https://doi. org/10.1007/s10661-014-4135-5.

vii. Kouba, A., Buric, M., and Kozak, P. (2010). Bioaccumulation and effects of heavy metals in crayfish: A Review. Water, Air and Soil Pollution, 211: 5-16.

viii. Kumar, H. and Hema, A. (2007). Heavy metal accumulation in certain marine animals along the East Coast of Chennai, Tamil Nadu. India Journal of Environmental Biology 28(3): 637-643.

ix. Morse, J., Bae, Y., and Munkhjargal, G. (2007). Freshwater biomonitoring with macro-invertebrates in East Asia. Frontiers in Ecology and the Environment, 5(1):33-42.

x. Nriagu, J. (2007). Zinc toxicity in humans. School of Public Health, University of Michigan, 1-7.

xi. Ostos, C., Pérez-Rodríguez, F., Arroyo, B., and Moreno-Rojas, R. (2015). Study of mercury content in wild edible mushrooms and its contribution to the provisional tolerable weekly intake in Spain. Journal of Food Composition and Analysis, 37:136-142. https://doi.org/10.1016/j.jfca.2014.04.014. 
xii. $\quad$ Peng, Q., Nunes, L., Greenfield, B., Dang, F., and Zhong, H. (2016). Are Chinese consumers at risk due to exposure to metals in crayfish? A bioaccessibility-adjusted probabilistic risk assessment. Environment International, 88: 261268.

xiii. Prendez, M. and Carrasco, M. (2003). Elemental composition of surface waters in the Antarctic Peninsula and interactions with the environment. Environmental Geochemistry and Health, 25: 347-363.

xiv. Saha, N., Mollah, M., Alam, M., and Rahman, M. (2016). Seasonal investigation of heavy metals in marine fishes captured from the Bay of Bengal and the implications for human health risk assessment. Food Control, 70: 110118.

xv. Samuel, J., Stanley, J., Princess, R., Shanthi, P., and Sebastian, M. (2011). Gestational cadmium exposure-induced ovotoxicity delays puberty through oxidative stress and impaired steroid hormone levels. Journal of Medical Toxicology, 7(3): 195- 204.

xvi. Shaheen, N., Irfan, N., Khan, I., Islam, S., Islam, M., and Ahmed, M. (2016). Presence of heavy metals in fruits and vegetables: health risk implications in Bangladesh. Chemosphere, 152: 431-438. https://doi.org/10.1016/j.

xvii. Tunca, E., Ucuncu, E., Ozkan, A., Ulger, Z., and Cansizoglu, A. (2013). Tissue distribution and correlation profiles of heavy metals accumulation in the freshwater crayfish Astacus leptodatylus. Archives of Environmental Contamination and Toxicology,64: 676-691.

xviii. Varol, M., and Şen, B. (2012). Assessment of nutrient and heavy metal contamination in surface water and sediments of the upper Tigris River, Turkey. CATENA, 92:1-10. doi:10.1016/j.catena.2011.11.011.

xix. Vicente-Martorell, J., Galindo-Riaño, M., García-Vargas, M., and GranadoCastro, M. (2009). Bioavailability of heavy metals monitoring water, sediments and fish species from a polluted estuary. Journal of Hazardous Materials, 162(2-3): 823-36.

xx. Vilizzi, L. and Takan, A. (2016). Bioaccumulation of metals in common carp (Cyprinus capio L) from water bodies of Anatolia (Turkey). A review with implications for fisheries and human food consumption. Environmental Monitoring Assessment, 188: 243-251.

xxi. Vowotor, M. K., Hood, C. O., Sackey, S. S., Owusu, A., Tatchie, E., Nyarko, S., Osei, D. M., Mireku, K. K., Letsa, C. B., and Atieomo, S. M. (2014). An assessment of heavy metal pollution in sediment of a tropical lagoon. A case study of the Benya Lagoon, Komenda Edina Eguafo Abrem Municipality (KEEA), Ghana. Journal of Health and Pollution, 4 (6): $26-39$.

xxii. World Health Organization (WHO) (2004). Guidelines for drinking water quality. 3rd Edition. World health Organization, page 516.

xxiii. Yu, Y., Wang, X., Yang, D., Lei, B., Zhang, X., and Zhang, X. (2014). Evaluation of human health risks posed by carcinogenic and non-carcinogenic multiple contaminants associated with consumption offish from Taihu Lake, China. Food and Chemical Toxicology, 69: 86-93. https://doi.org/10.1016/j.fct.2014.04.001. 